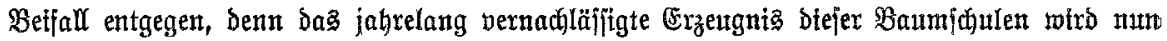

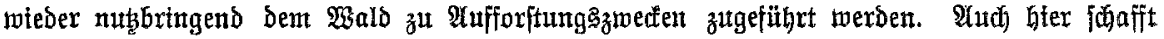

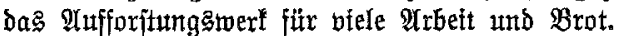

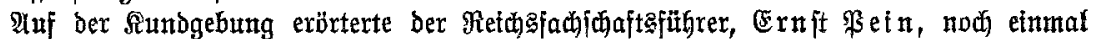

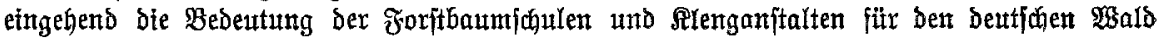

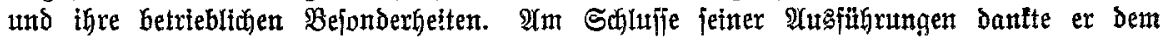

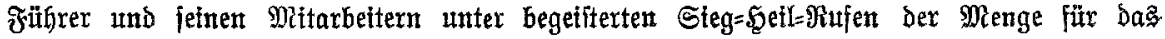

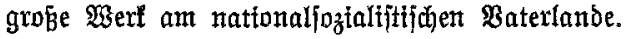

F. P. $1929 / 135$.

Berltn, Den 25. September 1934.

Vorlejungen für Studievende der forftwiffenfhaft im Winterhalbfahr 1934/35.

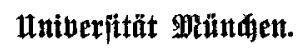

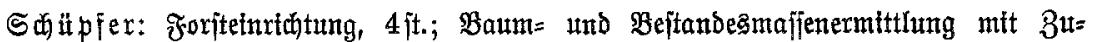

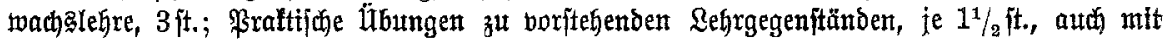

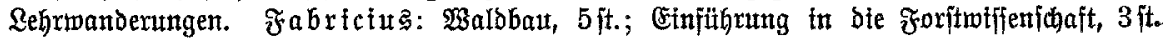

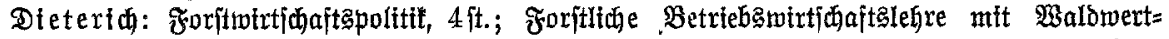

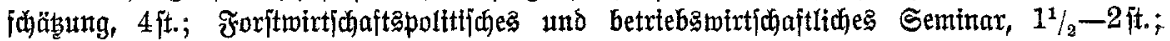

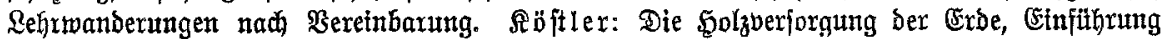

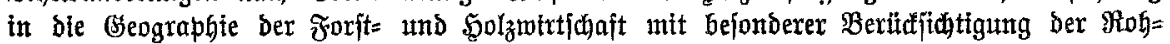

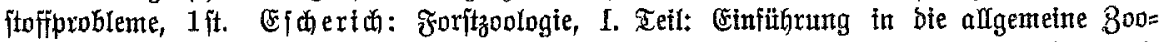

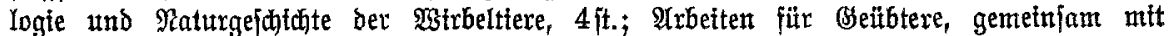
8wölfer. $\mathfrak{a} \mathfrak{n} \mathfrak{n}$ : Bermittertng

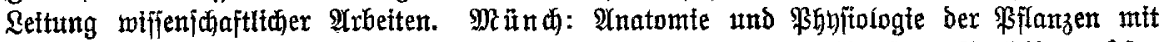

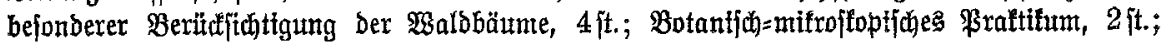

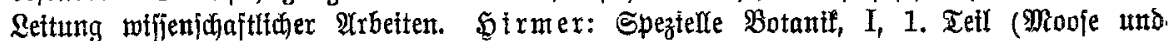

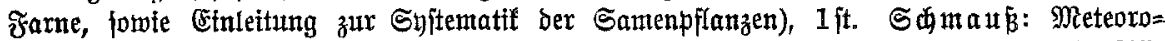

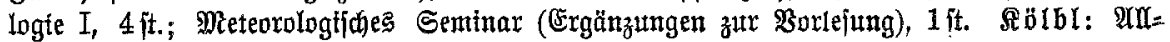
gemeine Bsologie, 4 ft. Bleyer: Erperimentaldamie 1. Teil, 4 ft. Rettenmeyer: Enn=

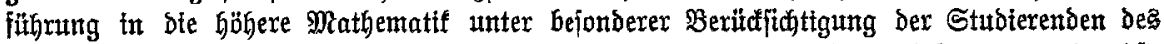

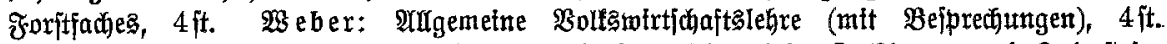

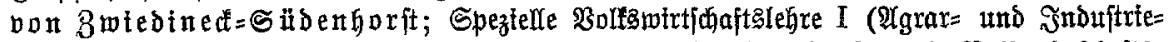

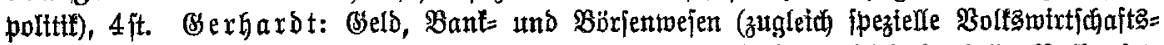

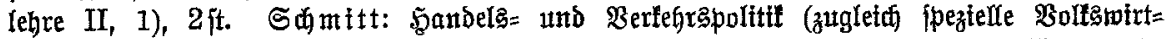

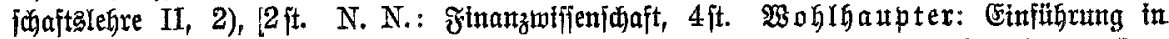

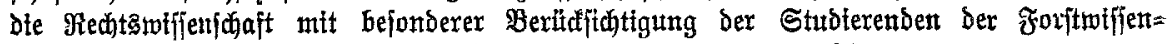

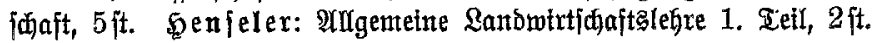

\title{
AEademifhe Lah̆riditen.
}

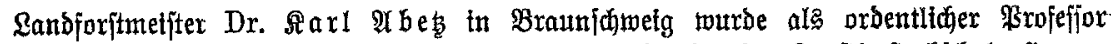

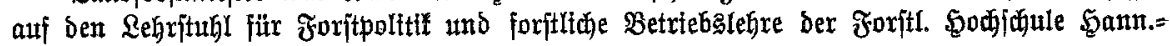
Münden berufen.

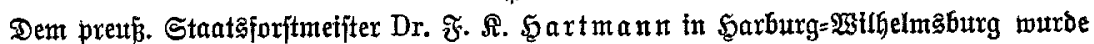

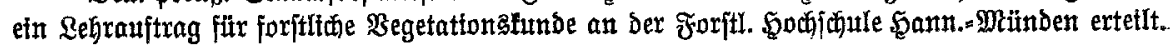

\section{Drudfehler.}

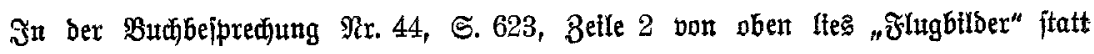
"శ̛htgblätter". 